\title{
Effect of acetic acid on fermentation performance of the immobilized yeast Kluyveromyces marxianus on Nypa fruticans leaf sheath pieces
}

- Vu Thi Le Quyen

- Le Van Viet Man

Ho Chi Minh city University of Technology, VNU-HCM.

(Manuscript Received on July, 2016, Manuscript Revised on September, 2016)

\begin{abstract}
The yeast cells of Kluyveromyces marxianus immobilized on Nypa fruticans leaf sheath pieces was tested for acetic acid tolerance during ethanol fermentation. Control sample with the free yeast cells were also performed under the same conditions. When the acetic acid content in the medium varied from 0 to $8 \mathrm{~g} / \mathrm{L}$, the cell growth rate of the immobilized and free yeast decreased by 8.3 to 10.3 time, respectively. In addition, increase in acetic acid content from immobilized and free yeast by 4.1 to 6.8 times, respectively. The immobilized yeast always demonstrated faster sugar assimilation and higher final ethanol concentration than the free yeast. Under acetic acid stress, the fixed yeast exhibited less change in unsaturated degree of fatty acids in cellular membrane than the free yeast. Application of immobilized yeast was therefore potential for improvement in ethanol fermentation from lignocellulosic material.
\end{abstract}

0 to $8 \mathrm{~g} / \mathrm{L}$ reduced ethanol formation rate of the

Keywords: acetic acid, bioethanol, Kluyveromycesmarxianus, Nypafruiticans.

\section{INTRODUCTION}

Lignocellulosic biomass such as wood, grass and agriculture residue have been reported as an attractive material for bioethanol production due to their abundance in nature and low cost $[1,2]$. In the production of bioethanol, pretreatment of lignocellulosic biomass is essential since this process can remove lignin and reduce the crystallinity of cellulose. As a result, hydrolysis of cellulose would be improved. There have been many pretreatment methods, among which weak acidic hydrolysis has been widely used because of low cost and high efficiency for lignin and hemicellulose removal [3, 4]. However, diluted acid pretreatment generates toxic compounds, such as weak acids, furans and phenolics, which strongly inhibit the biological reactions of yeast during the ethanol fermentation [5]. Among the 
toxic compounds, acetic acid affects the cellular physiology by changing the function of biological membranes $[3,6]$. In recent years, the immobilization of yeast has been evaluated as potential solution for protecting the yeast against unfavorable conditions and improving the rate of fermentation [7, 8]. For yeast immobilization, leaf sheath pieces was proved as appropriate support due to its high porosity for cell adsorption [9].

Kluyvermyces marxianus is considered as potential yeast species in ethanol industry because of its thermo-tolerance and ability to ferment both hexose and pentose $[10,11]$. It was reported that immobilization of $K$. marxianus cells on cellulosic support improved fermentation performance of this yeast [9]. However, the tolerance of the fixed yeast against toxic compounds from the acidic pretreatment of lignocellulosic biomass has not been reported. The objective of this study was to evaluate the effect of acetic acid on the growth, glucose assimilation and ethanol fermentation by the immobilized yeast $K$. marxianus on Nypa fruticans leaf sheath pieces. The unsaturation degree of fatty acid of cellular membrane was also examined to provide a clearer understanding about the response of the immobilized and free yeast under acetate stress.

\section{MATERIALS AND METHODS}

\subsection{Yeast}

Kluyveromyces marxianus used in this study was originated from the culture collection of Food Microbiology Laboratory, Food Technology Department, Ho Chi Minh City University of Technology. For the inoculum preparation, yeast strain was cultivated in the growth medium. The yeast growth was performed at $30^{\circ} \mathrm{C}, 150 \mathrm{rpm}$ for $24 \mathrm{~h}$. The preculture was subsequently centrifuged at 2000 rpm for $20 \mathrm{~min}$. The cells were then collected and used for fermentation (control sample) or yeast immobilization on Nypa fruticans leaf sheath pieces.

\subsection{Media}

The medium for inoculum preparation contained glucose $(40 \mathrm{~g} / \mathrm{L})$, yeast extract $(5 \mathrm{~g} / \mathrm{L})$, $\left(\mathrm{NH}_{4}\right)_{2} \mathrm{SO}_{4} \quad(2 \mathrm{~g} / \mathrm{L}), \quad \mathrm{KH}_{2} \mathrm{PO}_{4} \quad(2 \mathrm{~g} / \mathrm{L}) \quad$ and $\mathrm{MgSO}_{4} .7 \mathrm{H}_{2} \mathrm{O}(1 \mathrm{~g} / \mathrm{L})$. The medium composition for cell immobilization and ethanol fermentation was similar to that of medium for inoculum preparation except that the glucose concentration was adjusted to $80 \mathrm{~g} / \mathrm{L}$ and $150 \mathrm{~g} / \mathrm{L}$, respectively. The initial $\mathrm{pH}$ of the media was adjusted to 5.5. All media was sterilized at $121^{\circ} \mathrm{C}, 1 \mathrm{~atm}$ for $20 \mathrm{~min}$ before use.

\subsection{Support}

Nypa fruticans leaf sheath was collected from a farm in District 2, Ho Chi Minh City. After harvesting, Nypa fruticans leaf sheath was washed with potable water, cut into pieces $3 \times 3$ $\times 0.5 \mathrm{~cm}$, and sterilized at $121^{\circ} \mathrm{C}, 1$ atm for 20 min before use.

\subsection{Yeast immobilization}

The yeast cells were suspended in the medium for yeast immobilization with the cell concentration $2.5 \times 10^{7} \mathrm{cfu} / \mathrm{mL} ; 10 \mathrm{~g}$ of support was added into $500 \mathrm{~mL}$ Erlenmeyer flask containing $150 \mathrm{~mL}$ yeast suspension and the mixture was incubated in a thermostat shaker at $30^{\circ} \mathrm{C}$ for 12 hours. The support with immobilized yeast was removed and washed with sterile water three times. The cell density was $3.5 \times 10^{7} \mathrm{cfu} / \mathrm{g}$ wet support. The obtained 
immobilized yeast was ready for ethanol fermentation.

\subsection{Fermentation}

Static fermentation was conducted at $30^{\circ} \mathrm{C}$ in $500 \mathrm{~mL}$ Erlenmeyer flask containing $300 \mathrm{~mL}$. The inoculum size was $2 \times 10^{7} \mathrm{cfu} / \mathrm{mL}$. Control samples with the free cells were simultaneously performed under the same conditions. The fermentation was lasted for 84 hours.

\subsection{Analytical methods}

\subsubsection{Cell density in the yeast culture}

For the immobilized yeast culture, $1 \mathrm{~g}$ of the support was mixed with $99 \mathrm{~mL}$ distilled water and ground in the blender at $3500 \mathrm{rpm}$ for 5 min. The suspension obtained was used for evaluation of the cell density by plate count agar at $30^{\circ} \mathrm{C}$ for 48 hours [9]. The result was calculated and expressed in number of colonies per $1 \mathrm{~mL}$ of culture.

For free yeast culture, number of yeast cells was also evaluated by plate count agar under the same conditions.

\subsubsection{Glucose concentration}

Glucose concentration was determined by spectrophotometric method, using 3,5 dinitrosalicylic acid (DNS) reagent. Glucose concentration was expressed in $\mathrm{g} / \mathrm{L}$ [12].

\subsubsection{Ethanol concentration}

Ethanol concentration was determined by high performance liquid chromatography (Shimazu, Japan) using Sugar SH101 column (8m ID x $300 \mathrm{~mm}$ ). $30 \mu \mathrm{L}$ of the sample filtered through $0.22 \mu \mathrm{m}$ cellulose acetate membrane (Millipore, Milford, MA) was pumped to the column operated at $75^{\circ} \mathrm{C}$. The samples were eluted with $0.01 \mathrm{M}$ sulfuric acid at a flow rate of
$1 \mathrm{~mL} / \mathrm{min}$. The eluting compounds were detected by refractive index detector (RID-10A).

\subsubsection{Fatty acid composition of yeast cell} membrane

$2 \mathrm{~g}$ of the harvested yeast biomass was used for evaluation of fatty acid composition of yeast cell membrane. The yeast biomass was mixed with $50 \mathrm{~mL}$ methanol and treated with ultrasound at power of $5 \mathrm{~W} / \mathrm{g}$ for $1 \mathrm{~min}$. The lipid extraction was carried out by chloroform and methanol $(2: 1 \mathrm{v} / \mathrm{v})$, and the weight ratio of material and solvent was 5:2. The extraction was performed at the ambient temperature, 200rpm for $2 \mathrm{~h}$. At the end of the extraction, $0.8 \%$ potassium chloride was added until the lower layer was clear. The mixture was then centrifuged at $25^{\circ} \mathrm{C}$, $3000 \mathrm{rpm}$ for $5 \mathrm{~min}$. The organic phase was then collected and used for determination of fatty acid compositions [13].

Fatty acid composition of yeast membrane was evaluated by gas chromatography using a Hewlett-Packard model 5890A (Hewlett Packard, The United States). The extract was injected into an FFAP-HP column of $25 \mathrm{~m} \times 0.2$ $\mathrm{mm}$ with an HP automatic injector. Helium was used as carrier gas at $1.0 \mathrm{~mL} \cdot \mathrm{min}^{-1}$ and heptadecanoic acid methyl ester $\left(1 \mu \mathrm{g} . \mu \mathrm{L}^{-1}\right)$ was added as an internal standard. Column inlet pressure was $150 \mathrm{kPa}$. The injector temperature was $250^{\circ} \mathrm{C}$. Detector temperature was $250^{\circ} \mathrm{C}$. The temperature program was $25^{\circ} \mathrm{C} . \mathrm{min}^{-1}$ from $70^{\circ} \mathrm{C}$ to $200^{\circ} \mathrm{C}$. Peak areas were measured using a Hewlett-Packard model 3396A integrator.

\subsubsection{Calculation formulas}

Yeast growth rate:

$$
\bar{X}=\frac{\Delta X_{1}}{\tau_{1}}(\mathrm{cfu} / \mathrm{mL} \cdot \mathrm{h})
$$


Glucose consumption rate:

$$
K_{s}=\frac{\Delta S}{\tau_{\mathrm{z}}}(\mathrm{g} / \mathrm{L} \cdot \mathrm{h})
$$

Ethanol formation rate:

$$
K_{P}=\frac{\Delta P}{\tau_{2}}(\mathrm{~g} / \mathrm{L} \cdot \mathrm{h})
$$

Glucose utilization efficiency:

$$
\eta=\frac{\Delta S}{s_{0}} \times 100(\%)
$$

$\tau_{1}$ : Fermentation time during which the cell density in the culture achieved maximum (hours); $\tau_{2^{x}}$ Ethanol fermentation time (hours); $\Delta X_{\mathrm{a}}$ : Difference between the maximum cell concentration in the culture and the initial cell concentration in the medium $(\mathrm{cfu} / \mathrm{mL}) ; \Delta S$ : Content of sugar assimilated by yeast during the fermentation $(\mathrm{g} / \mathrm{L}) ; \Delta P_{3}$ Content of ethanol produced by the yeast during the fermentation $(\mathrm{g} / \mathrm{L}) ; \mathrm{s}_{\mathrm{g}} \mathrm{x}$ Initial sugar concentration in the medium $(\mathrm{g} / \mathrm{L})$.

Unsaturation degree of fatty acids in yeast cell membrane

Unsaturation degree of fatty acids in the yeast cell membrane is calculated from the fatty acid composition in cellular membrane using the following formula [13]:

$$
\underset{\left.\mathrm{x}_{2} * 2+\ldots+\mathrm{x}_{\mathrm{n}} * \mathrm{n}\right) / 100}{\text { Unsaturated degree }}=\left(\mathrm{x}_{1} * 1+\right.
$$

$\mathrm{x}_{1}$ : Percentage of fatty acid containing 1 double bond; $\mathrm{x}_{2}$ : Percentage of fatty acid containing 2 double bond; $\mathrm{x}_{\mathrm{n}}$ : Percentage of fatty acid containing $\mathrm{n}$ double bond.
Percentage of undissociated acetic acid and acetate anion in the media was calculated by using the Henderson-Hasselbach equation [14].

\subsection{Statistical analysis}

All experiments were triplicated. The results are expressed as means \pm standard deviations. Mean values was considered significantly different when $\mathrm{P}<0.05$. Analysis of variance was performed with Stagraphic Centurion software.

\section{RESULTS AND DISCUSSION}

\subsection{Effect of acetic acid on yeast growth}

Yeast growth was evaluated by maximum cell density and growth rate during the ethanol fermentation (Table 1). The maximum cell density of the immobilized and free yeast decreased by 2.5 and 2.8 times, respectively when the acetic acid concentration in the medium was varied from 0 to $8 \mathrm{~g} / \mathrm{L}$. In addition, increase in acetic acid concentration from 0 to $8 \mathrm{~g} / \mathrm{L}$ reduced the growth rate of the immobilized and free yeast by 8.33 times and 10.34 times, respectively. Similar growth inhibition was previously reported for Saccharomyces cerevisiae; when the acetic acid content in the medium was $9 \mathrm{~g} / \mathrm{L}$, the growth rate of the free Saccharomyces cerevisiae cells decreased by $33 \%$ in comparison with the control sample [15]. The inhibition of yeast growth was reported due to the undissociated form of acetic acid [16]. This effect linked to the different permeability of the plasma membrane and depended on the concentration of the undissociated acid form. The higher the acetic acid content in the medium, the higher the level of undissociated form of acetic acid. 
Table 1. Maximum cell density and average growth rate of the immobilized and free cells in medium with different acetic acid concentrations

\begin{tabular}{|c|c|c|c|c|}
\hline \multirow{2}{*}{$\begin{array}{c}\text { Acetic } \\
\text { acid } \\
\begin{array}{c}\text { concentration } \\
(\mathrm{g} / \mathrm{L})\end{array}\end{array}$} & Free cells & Immobilized cells & Free cells & Immobilized cells \\
\cline { 2 - 5 } & $156 \pm 0.89^{\mathrm{f} 1}$ & $244 \pm 0.29^{\mathrm{h} 1}$ & $6.00 \pm 0.10^{\mathrm{i} 2}$ & $9.04 \pm 0.13^{\mathrm{k} 2}$ \\
\hline 0 & $123 \pm 1.22^{\mathrm{de} 1}$ & $226 \pm 0.88^{\mathrm{k} 1}$ & $4.29 \pm 0.1^{\mathrm{g} 2}$ & $8.58 \pm 1.19^{\mathrm{h} 2}$ \\
\hline 2 & $99 \pm 0.86^{\mathrm{c} 1}$ & $191 \pm 0.21^{\mathrm{g} 1}$ & $3.19 \pm 0.12^{\mathrm{f} 2}$ & $7.13 \pm 0.19^{\mathrm{j} 2}$ \\
\hline 4 & $71 \pm 0.12^{\mathrm{b} 1}$ & $118 \pm 0.61^{\mathrm{d} 1}$ & $1.42 \pm 0.86^{\mathrm{d} 2}$ & $2.04 \pm 0.10^{\mathrm{e} 2}$ \\
\hline 6 & $55 \pm 0.14^{\mathrm{a} 1}$ & $92 \pm 0.53^{\mathrm{c} 1}$ & $0.58 \pm 1.00^{\mathrm{b} 2}$ & $1.08 \pm 1.02^{\mathrm{c} 2}$ \\
\hline 8 & & & & \\
\hline
\end{tabular}

Values with different letters in the same row are significantly different $(\mathrm{p}<0.05)$

Table 2. Percentages of undissociated acetic acid and acetate anions in the investigated media with various acetic acid concentrations

\begin{tabular}{|c|c|c|c|c|}
\hline \multirow{2}{*}{$\begin{array}{c}\text { Acetic acid } \\
\text { concentration } \\
(\mathrm{g} / \mathrm{L})\end{array}$} & \multirow{2}{*}{$\mathrm{pH}^{*}$} & \multirow{2}{*}{$\begin{array}{c}\text { Concentration of } \\
\text { undissociated acetic } \\
\text { acid }(\mathrm{g} / \mathrm{L})^{* *}\end{array}$} & \multicolumn{2}{|c|}{ Percentage of } \\
\hline & & & $\begin{array}{l}\text { Undissociated acetic } \\
\text { acid }(\%)\end{array}$ & $\begin{array}{c}\text { Acetate } \\
\text { anion }(\%)\end{array}$ \\
\hline 2 & 3.87 & 1.73 & 86.50 & 13.50 \\
\hline 4 & 3.66 & 3.67 & 91.75 & 8.25 \\
\hline 6 & 3.53 & 5.64 & 94.00 & 6.00 \\
\hline 8 & 3.34 & 7.69 & 96.13 & 3.87 \\
\hline
\end{tabular}

*Values were means of triplicate samples

**Values were calculated using the Henderson-Hasselbach equation and $\mathrm{p} K_{\mathrm{a}}$ value of acetic acid was 4.74

Table 2 shows that the ratio of undissociated form of acetic acid in the media varied from
$86.50 \%$ to $96.13 \%$. In order to maintain a proper $\mathrm{pH}$ gradient inside the cell, the extra protons must 
be pumped out at the cost of ATP via membrane ATPase, which caused the reduced growth rate [14]. The immobilized yeast on Nypa fruiticans leaf sheath pieces was more tolerant to acetic acid than the free yeast. The maximum cell density in the fixed cell cultures was 1.4 to 1.9 times higher than that in the free cell cultures. It can be explained that the Nypa fruitican leaf sheath pieces protected the cells against acetic acid stress. This finding was similar to that in the previous study with the immobilized Saccharomyces cerevisiae cells in Ca-alginate gel under acetate stress [17].

\subsection{Effect of acetic acid on substrate assimilation}

Table 3 shows residual glucose level and glucose uptake rate. When the initial acetic acid concentration varied from 0 to $2 \mathrm{~g} / \mathrm{L}$, the residual glucose level and glucose utilization efficiency were unchanged for both the fixed and free yeast.

However, the glucose uptake rate of the fixed and free cells was reduced by $7.83 \%$ and $5.91 \%$, respectively.

Increase in acetic acid concentration in the medium from 2 to $8 \mathrm{~g} / \mathrm{L}$ significantly decreased glucose assimilation efficiency. The higher acetic acid concentration in the medium, the higher residual glucose concentration in the culture and the lower glucose uptake rate. Similar result was previously reported for the free Saccharomyces cerevisiae cells in ethanol fermentation when the concentration of acetic acid in medium increased from 0 to $170 \mathrm{mM}$ [18]. Nevertheless, the immobilized yeast $K$. marxianus on Nypa fruticans leaf sheath pieces fermented sugar much faster than the free yeast. The glucose uptake rateof the immobilized cells was 1.1 to 3.1 times faster than that of the free cells.

Table 3. The residual glucose level and glucose uptake rate of the immobilized and free yeast cultures with different acetic acid concentrations

\begin{tabular}{|c|c|c|c|c|c|}
\hline \multirow{2}{*}{$\begin{array}{c}\text { Acetic acid } \\
\begin{array}{c}\text { concentration } \\
(\mathrm{g} / \mathrm{L})\end{array}\end{array}$} & $\begin{array}{c}\text { Glucose } \\
\text { utilization } \\
\text { efficiency } \\
(\%)\end{array}$ & \multicolumn{2}{|c|}{ Residual glucose level $(\mathrm{g} / \mathrm{L})$} & \multicolumn{2}{c|}{ Glucose uptake rate $(\mathrm{g} / \mathrm{L} . \mathrm{h})$} \\
\cline { 3 - 6 } & 90 & $8.19 \pm 0.35^{\mathrm{a} 1}$ & $2.02 \pm 0.04^{\mathrm{a} 1}$ & $1.86 \pm 0.01^{\mathrm{f} 2}$ & $4.72 \pm 0.05^{\mathrm{k} 2}$ \\
\hline 0 & 90 & $5.96 \pm 0.02^{\mathrm{a} 1}$ & $1.39 \pm 0.03^{\mathrm{a} 1}$ & $1.75 \pm 0.07^{\mathrm{d} 2}$ & $4.35 \pm 0.02^{\mathrm{gh} 2}$ \\
\hline 2 & 70 & $37.49 \pm 0.11^{\mathrm{b} 1}$ & $1.11 \pm 0.06^{\mathrm{a} 1}$ & $1.36 \pm 0.03^{\mathrm{c} 2}$ & $4.25 \pm 0.01^{\mathrm{g} 2}$ \\
\hline 4 & 60 & $54.28 \pm 7.77^{\mathrm{c} 1}$ & $38.77 \pm 4.39^{\mathrm{b} 1}$ & $1.19 \pm 0.02^{\mathrm{b} 2}$ & $2.23 \pm 0.01^{\mathrm{e} 2}$ \\
\hline 6 & 35 & $88.62 \pm 3.23^{\mathrm{e} 1}$ & $74.66 \pm 4.60^{\mathrm{d} 1}$ & $1.02 \pm 0.04^{\mathrm{ab} 2}$ & $0.96 \pm 0.04^{\mathrm{a} 2}$ \\
\hline 8 & & Freells cells & $\begin{array}{c}\text { Immobilized } \\
\text { cells }\end{array}$ & & \\
\hline
\end{tabular}

Values with different letters in the same row are significantly different $(\mathrm{p}<0.05)$ 
Table 4. Final ethanol concentration, ethanol formation rate of the immobilized and free yeast in media with different acetic acid concentrations

\begin{tabular}{|c|c|c|c|c|}
\hline \multirow{2}{*}{\begin{tabular}{c}
\multirow{2}{*}{$\begin{array}{c}\text { Acetic acid } \\
\text { concentration }(\mathrm{g} / \mathrm{L})\end{array}$} \\
\cline { 2 - 5 }
\end{tabular}} & \multicolumn{2}{|c|}{ Free cells } & $\begin{array}{c}\text { Immobilized } \\
\text { cells }\end{array}$ & \multicolumn{2}{c|}{$\begin{array}{c}\text { Ethanol } \\
\text { Free cells } \\
\text { formal ethanol concentration }(\%, \mathrm{w} / \mathrm{w})\end{array}$} & $\begin{array}{c}\text { Immobilize } \\
\mathrm{d} \text { cells }\end{array}$ \\
\hline 0 & $7.1 \pm 0.14^{\mathrm{f} 1}$ & $7.18 \pm 0.05^{\mathrm{f} 1}$ & $0.98 \pm 0.53^{\mathrm{e} 2}$ & $2.50 \pm 0.27^{\mathrm{g} 2}$ \\
\hline 2 & $6.26 \pm 0.19^{\mathrm{e} 1}$ & $7.25 \pm 0.06^{\mathrm{f} 1}$ & $0.82 \pm 0.45^{\mathrm{d} 2}$ & $1.87 \pm 0.80^{\mathrm{f} 2}$ \\
\hline 4 & $5.32 \pm 0.09^{\mathrm{d} 1}$ & $7.18 \pm 0.04^{\mathrm{f} 1}$ & $0.69 \pm 0.16^{\mathrm{c} 2}$ & $1.02 \pm 0.13^{\mathrm{e} 2}$ \\
\hline 6 & $3.09 \pm 0.41^{\mathrm{c} 1}$ & $4.99 \pm 0.04^{\mathrm{d} 1}$ & $0.40 \pm 0.17^{\mathrm{b} 2}$ & $0.68 \pm 0.36^{\mathrm{c} 2}$ \\
\hline 8 & $1.36 \pm 0.02^{\mathrm{a} 1}$ & $1.91 \pm 0.08^{\mathrm{b} 1}$ & $0.24 \pm 0.08^{\mathrm{a} 2}$ & $0.37 \pm 0.04^{\mathrm{b} 2}$ \\
\hline
\end{tabular}

Values with different letters in the same row are significantly different $(\mathrm{p}<0.05)$

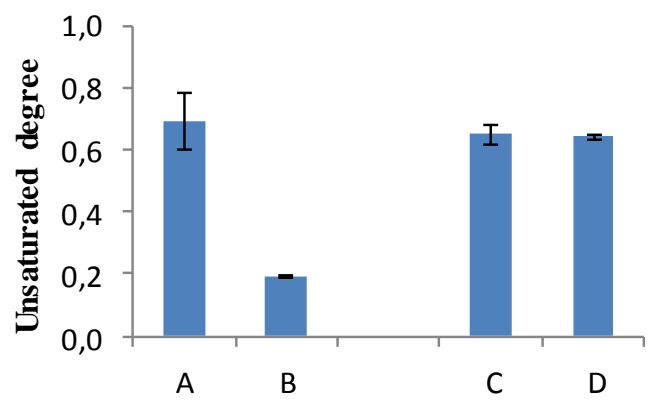

Figure 1. The unsaturated degree of fatty acid on the cell membrane

A: Free yeast at the beginning of ethanol fermentation; B: Free yeast at the end of ethanol fermentation in $6 \mathrm{~g} / \mathrm{L}$ acetic acid medium; $C$ : Immobilized yeast at the beginning of ethanol fermentation; D: Immobilized yeast at the end of ethanol fermentation in $6 \mathrm{~g} / \mathrm{L}$ acetic acid medium.
The response of yeast to environmental stress was reported by changing their fatty acid composition [19, 20]. In order to clarify the effect of acetic acid on the substrate assimilation rate of the immobilized and free yeast during ethanol fermentation, the fatty acid composition of yeast cell membrane was determined (Fig. 1). It can be noted that in medium with $6 \mathrm{~g} / \mathrm{L}$ acetic acid, the unsaturated degree of membrane fatty acid of the free yeast at the end of the fermentation was much lower than that at the beginning of the fermentation. Previous study had similar trends.

According to the authors, increase in ethanol stress led to a decrease in unsaturated degree of fatty acid [21]. On the contrary, the unsaturation degree of membrane fatty acid of 
the immobilized yeast was nearly unchanged during the fermentation.

Reduction in the unsaturated fatty acid degree for the free yeast showed that the free yeast was more sensitive to acetic acid than the fixed yeast. The previous study also noted that more change in unsaturated fatty acid degree for the free $K$. marxianus cells than the fixed cells on banana leaf sheath pieces under thermal stress [9].

\subsection{Effect of acetic acid on ethanol formation}

Table 4 presented the final ethanol concentration and ethanol formation rate of the immobilized and free cells. In the free acetic acid medium, the final ethanol concentration of the fixed and free yeast was similar. Increase in initial acetic acid content from 0 to $8 \mathrm{~g} / \mathrm{L}$ in the medium reduced the final ethanol concentration by 3.76 and 5.22 times for the immobilized and free yeast, respectively. Moreover, the ethanol content produced by the immobilized cells was 1.1 to 1.6 times higher than that generated by the free cells. It was probably due to higher biomass content of the fixed cells in comparison with that of the free cells. Similar finding on the immobilized Saccharomyces cerevisiae cells in Ca-alginate gel and cellulose beads under acetic acid stress were previously reported [17].

Increase in acetic acid level in the medium from 0 to $8 \mathrm{~g} / \mathrm{L}$ reduced the ethanol formation rate by 6.8 and 4.08 times for the fixed and free cells, respectively. At all acetate levels, the ethanol formation rate of the fixed yeast were 1.5 to 2.6 times higher than that of the free yeast. Our results proved that acetic acid inhibited yeast growth, glucose assimilation and ethanol production but the immobilized yeast alwaysshowed better fermentation performance than the free yeast.

\section{CONCLUSIONS}

Acetic acid inhibited the growth of $K$. marxianus, glucose assimilation and ethanol production but the immobilized yeast always showed better fermentation performance than the free yeast. The fixed yeast exhibited less change in unsaturated degree of fatty acids in cellular membrane than the free yeast. Using immobilized yeast on Nypa fruticans leaf sheath pieces improved ethanol fermentation under acetic acid stress. 
Khảo sát khả năng trao đổi chất của nấm men Kluyveromyces marxianus được cố định trên chất mang bẹ lá dừa nước trong điều kiện stress acetic acid

- Vũ Thị Lệ Quyên

- Lê Văn Việt Mẫn

Trường Đại học Bách Khoa, ĐHQG-HCM

\section{TÓM TẮT}

Khả năng kháng chịu stress acetic acid của nấm men Khuyveromyces marxianus được cố định trên chất mang be lá dìa nước được khảo sát thông qua khả năng sinh trương, sủ dụng co chất và sinh tổng hợp ethanol. Mẫu đối chứng được thực hiện trên nấm men tụ do trong cùng điều kiện lên men. Kết quả cho thấy, khi tăng nồng độ acetic acid ban đầu trong môi truờng tù 0 đến $8 \mathrm{~g} / \mathrm{L}$, tốc độ sinh trương của nấm men tụ do và nấm men cố định đều giảm lần luợt 8.3 và 10.3 lần. Khi tăng nồng độ acetic acid trong môi trường lên men lên $8 \mathrm{~g} / \mathrm{L}$, tốc độ sinh tổng hợp ethanol của nấm men cố định và nấm men tụ do cũng lần luợt giảm 4.1 và 6.8 lần so vói mẫu không bổ sung chất ức chế. Đồng thời, nấm men cố định trên bẹ lá dìa nuoớc thể hiện khả

năng sủ dụng đường tốt hơn nấm men tụ do trong diều kiện stress acetic acid. Hàm luọng ethanol aượ sinh ra trong quá trình lên men của nấm men cố định luôn cao hơn so với nấm men tụ do ở các nghiệm thức khảo sát. Trong môi trưòng chứa acetic acid, độ bất bão hoà của các acid béo trong màng tế bào chất của nấm men giảm dần theo thời gian lên men. Tuy nhiên, nấm men cố định có độ bất bão hoà cao hơn so với nấm men tụ do ở cuối quá trình lên men. Các kết quả thu được tù̀ nghiên cưu cho thấy ứng dụng nấm men cố định trong quá trình lên men ethanol tù̀ các nguyên liệu giàu cellulose có nhiều un điểm so với nấm men tụ do.

Tù khóa: acetic acid, bioethanol, Kluyveromyces marxianus, Nypa fruiticans.

\section{REFERENCES}

[1]. Hamelinck, C.N., G.v. Hooijdonk, and A.P. Faaij, "Ethanol from lignocellulosic biomass: techno-economic performance in short-, middle-and long-term", Biomass and bioenergy, vol. 28, pp. 384-410(2005)

[2]. Lavigne, A. and S.E. Powers, "Evaluating fuel ethanol feedstocks from energy policy perspectives: A comparative energy 
assessment of corn and corn stover", Energy Policy, vol 35, pp. 59185930(2007)

[3]. Saha, B.C., "Hemicellulose bioconversion. Journal of Industrial Microbiology and Biotechnology", vol 30, pp. 279-291 (2003)

[4]. Carvalheiro, F., Duarte, LC., Lopes, S., Parajó, JC., Pereira, H. and Gırio, FM., "Evaluation of the detoxification of brewery's spent grain hydrolysate for xylitol production by Debaryomyces hansenii CCMI 941", Process Biochemistry, vol 40, pp. 1215-1223 (2005)

[5]. Palmqvist, E., Palmqvist, E., Grage, H., Meinander, N. Q., Hahn-Hägerdal, B., "Main and interaction effects of acetic acid, furfural, and p-hydroxybenzoic acid on growth and ethanol productivity of yeasts", Biotechnology and Bioengineering, vol 63, pp. 46-55 (1999)

[6]. Sun, Y. and J. Cheng, "Hydrolysis of lignocellulosic materials for ethanol production: a review", Bioresource technology, vol 81, p p. 1-11 (2002)

[7]. Williams, D. and D.M. Munnecke, "The production of ethanol by immobilized yeast cells. Biotechnology and Bioengineering", vol 23, pp. 1813-1825 (1981)

[8]. Kourkoutas, Y., Kourkoutas, Y., Bekatorou, A, Banat, I Mm., Marchant, Roger and Koutinas, AA., "Immobilization technologies and support materials suitable in alcohol beverages production: a review”, Food Microbiology, vol 21, pp. 377-397 (2004)

[9]. Du Le, H., P. Thanonkeo and Le, V.V.M, "Impact of high temperature on ethanol fermentation by Kluyveromyces marxianus immobilized on banana leaf sheath pieces", Applied biochemistry and biotechnology, vol 171, pp. 806-816(2013)

[10]. Lane, M.M. and J.P. Morrissey, "Kluyveromyces marxianus: A yeast emerging from its sister's shadow", Fungal Biology Reviews, vol 24, pp. 17-26(2010)

[11]. Fonseca, G.G., Fonseca, G.G., Heinzle, E., Wittmann, C., Gombert, A. K., "The yeast Kluyveromyces marxianus and its biotechnological potential”, Applied microbiology and biotechnology, vol 79, pp. 339-354(2008)

[12]. Miller, G.L., "Use of dinitrosalicylic acid reagent for determination of reducing sugar", Analytical chemistry, vol 31, pp. 426-428(1959)

[13]. Beltran, G., Beltran, G., Novo, M.,Guillamón, J. M, Mas, A.,Rozès, N., "Effect of fermentation temperature and culture media on the yeast lipid composition and wine volatile compounds", International journal of food microbiology, vol 121, pp. 169-177(2008)

[14]. Narendranath, N., K. Thomas, and W. Ingledew, "Effects of acetic acid and lactic acid on the growth of Saccharomyces cerevisiae in a minimal medium", Journal of Industrial Microbiology and Biotechnology, vol 26, pp. 171-177(2001)

[15]. Lindberg, L., Lindberg, L., Santos, AX., Riezman, H., Olsson, L., Bettiga, M., 
"Lipidomic profiling of Saccharomyces cerevisiae and Zygosaccharomyces bailii reveals critical changes in lipid composition in response to acetic acid stress", PloS one, vol 8, pp. e73936(2013)

[16]. Giannattasio, S., Giannattasio, S., Guaragnella, N., Ždralević, M.,Marra, E., "Molecular mechanisms of Saccharomyces cerevisiae stress adaptation and programmed cell death in response to acetic acid". Frontiers in microbiology, vol 4, (2013)

[17]. Krisch, J. and B. Szajani, "Ethanol and acetic acid tolerance in free and immobilized cells of Saccharomyces cerevisiae and Acetobacter aceti", Biotechnology letters, vol 19, pp. 525528(1997)

[18]. Pampulha, M.E. and M.C. Loureiro-Dias, "Energetics of the effect of acetic acid on growth of Saccharomyces cerevisiae",
FEMS microbiology letters, vol 184, pp. 69-72(2000)

[19]. Ohta, K. and S. Hayashida, "Role of Tween 80 and monoolein in a lipid-sterolprotein complex which enhances ethanol tolerance of sake yeasts" Applied and environmental microbiology, vol 46, pp. 821-825 (1983)

[20]. Ingram, L., "Microbial tolerance to alcohols: role of the cell membrane", Trends in Biotechnology, vol 4, pp. 4044(1986)

[21]. Nguyen, H.P., Le, H.D and Le, V.V.M., "Effect of ethanol stress on fermentation performance of Saccharomyces cerevisiae cells immobilized on Nypa fruticans leaf sheath pieces", Food Technology and Biotechnology, vol 53, pp. 96-101 (2015). 